\title{
Palladium-catalyzed esterification of aryl halides using aryl formates without the use of external carbon monoxide.
}

\section{AUTHOR(S):}

Fujihara, Tetsuaki; Hosoki, Tomoya; Katafuchi, Yuko; Iwai, Tomohiro; Terao, Jun; Tsuji, Yasushi

\section{CITATION:}

Fujihara, Tetsuaki ...[et al]. Palladium-catalyzed esterification of aryl halides using aryl formates without the use of external carbon monoxide.. Chemical communications 2012 , 48: 8012-8014

\section{ISSUE DATE:}

\section{2-08-18}

\section{URL:}

http://hdl.handle.net/2433/175813

\section{RIGHT:}

(C) The Royal Society of Chemistry 2012; This is not the published version. Please cite only the published version.; この論文は出版社版で ありません。引用の際には出版社版をご確認ご利用ください。 


\title{
Palladium-catalyzed esterification of aryl halides using aryl formates without the use of external carbon monoxide $\uparrow$
}

\author{
Tetsuaki Fujihara, Tomoya Hosoki, Yuko Katafuchi, Tomohiro Iwai, Jun Terao, and Yasushi Tsuji* \\ Received (in $X X X, X X X) X$ th $X X X X X X X X X 20 X X$, Accepted Xth $X X X X X X X X X 20 X X$ \\ ${ }_{5}$ DOI: 10.1039/b000000x
}

Aryl formates are efficient carbon monoxide sources in palladium-catalyzed esterification of aryl halides. The carbonylation readily proceeds at ambient pressure without the use of external carbon monoxide to afford the ${ }_{10}$ corresponding esters in high yields.

Carbonylation processes using carbon monoxide (CO) as carbonyl sources constitute industrial core technologies for converting various bulk chemicals into functionalized useful products. $^{1}$ Despite large-scale applications in industry, 15 carbonylations with $\mathrm{CO}$ are not comparatively used for more complex organic syntheses. This might be due to general reluctance to use the toxic gas as reagents and frequent use of a high-pressure reactor. Therefore, carbonylation reactions without the use of external CO is highly desirable. ${ }^{2}$ As for the CO source, 20 formic acid and its esters are industrially produced from $\mathrm{CO}$. Thus, formate esters may be regarded as liquid condensates and expedient alternative sources of CO. Actually, much effort has been made to realize carbonylation reaction employing formate esters as a $\mathrm{CO}$ source. ${ }^{3,4}$ However, the $\mathrm{CO}$ generation from usual 25 formate esters is not efficient and required relatively high reaction temperature, ${ }^{3 \mathrm{a}}$ co-catalysts, ${ }^{3 \mathrm{~b}}$ or strong bases. ${ }^{3 \mathrm{c}}$ Recently, Skrydstrup et al. reported ex situ generation of carbon monoxide utilizing several $\mathrm{CO}$ sources by the aid of palladium catalysts. ${ }^{5}$ Although CO generated efficiently and the carbonylation of aryl 30 halides proceeded, a two-chamber system must be used to separate $\mathrm{CO}$ generation and carbonylation processes.

We have recently found that aryl formates, not alkyl formate are very efficient $\mathrm{CO}$ source under relatively mild reaction conditions in the Pd-xantphos catalyzed hydroesterification of 35 alkynes. ${ }^{6}$ However, in the reactions, an excess amount (4 or 10 equiv) of aryl formates must be indispensable for high yields of products. Herein, we report the Pd-catalyzed esterification of aryl halides employing aryl formates as a CO source (Scheme 1). By simply mixing an aryl halides, an aryl formate, and a Pd catalyst

Scheme 1.

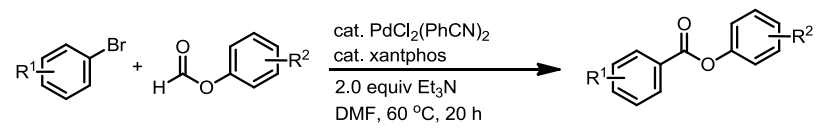

40 in a usual glass flask (no pressure bottle is required), highly efficient esterification of the aryl halide was realized. Noteworthy is that only one equivalent of aryl formates is enough to afford
Table 1 Effect of ligands on the palladium-catalyzed esterification of 4-bromotoluene (1a) with phenyl formate (2a). ${ }^{a}$

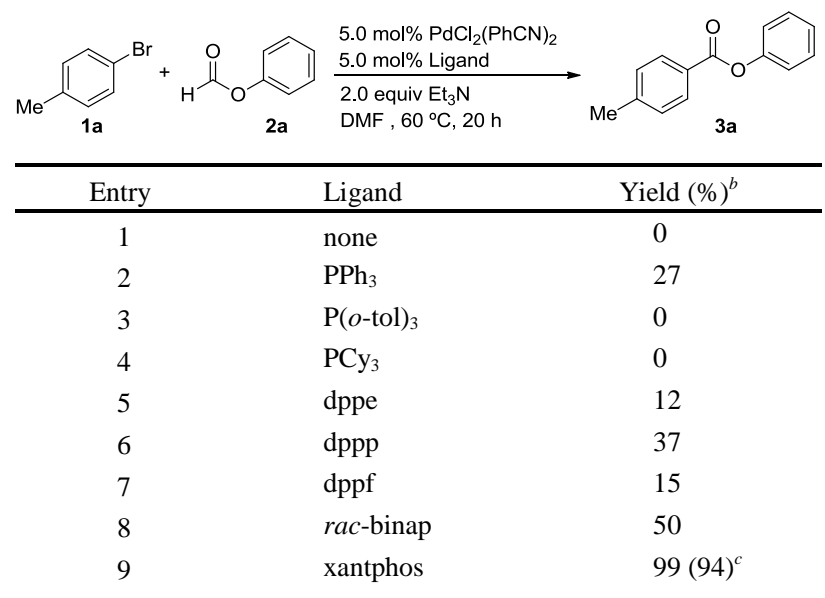

${ }^{a}$ Reaction conditions: 4-bromotoluene (1a, $\left.0.50 \mathrm{mmol}\right)$, phenyl formate (2a, $0.75 \mathrm{mmol}), \mathrm{PdCl}_{2}\left(\mathrm{PhCN}_{2}(0.025 \mathrm{mmol}, 5.0 \mathrm{~mol} \%)\right.$, phosphine $(0.025 \mathrm{mmol}), \mathrm{Et}_{3} \mathrm{~N}(1.0 \mathrm{mmol})$ in DMF $(0.5 \mathrm{~mL})$ at 60 ${ }^{\circ} \mathrm{C}$ for $20 \mathrm{~h} .{ }^{b}$ Yield based on the GC internal standard technique. ${ }^{c}$ Isolated Yield of $\mathbf{3 a}$.

the carbonylated products in high yields. ${ }^{7}$

First, the reaction of 4-bromotoluene (1a) with 1.5 45 equivalent of phenyl formate (2a) was carried out in the presence of a catalytic amount of $\mathrm{PdCl}_{2}(\mathrm{PhCN})_{2}$ in a $10-\mathrm{mL}$ glass flask equipped with a standard ground glass joint (Table 1$).{ }^{8}$ Without any ligand, phenyl 4-methylbenzoate (3a) was not obtained at all (entry 1). With an addition of monodentate phosphines such as ${ }_{50} \mathrm{PPh}_{3}, \mathrm{P}(\text { o-tol })_{3}$, or $\mathrm{PCy}_{3},{ }^{9}$ 3a was obtained in low yields (entries 2-4). The use of a bidentate phosphine such as dppe, dppp, dppf, or binap ${ }^{9}$ improved the catalytic activity (entries 5-8), although yields of the product were not satisfactory. Among the ligands examined, xantphos ${ }^{9,10}$ gave the best result, affording 3a in $99 \%$ 55 yield (entry 9$)$. As a base, $(i-\mathrm{Pr})_{2} \mathrm{EtN}, \mathrm{DBU}$, and $\mathrm{K}_{2} \mathrm{CO}_{3}$ afforded 3a in $82 \%, 70 \%$, and $57 \%$ yields, respectively, while pyridine and $\mathrm{KOH}$ did not provide $3 \mathbf{a}$ at all. Under the same reaction conditions as in entry 9, alkyl formates (benzyl formate, hexyl formate, and 2-phenylethyl formate) in place of $\mathbf{2 a}$ did not 60 convert and the corresponding esters were not provided at all. Thus, 2a is unique carbonyl source in the present carbonylation. 
Table 2 Conversion of phenyl formate (2a) to phenol and carbon monoxide.

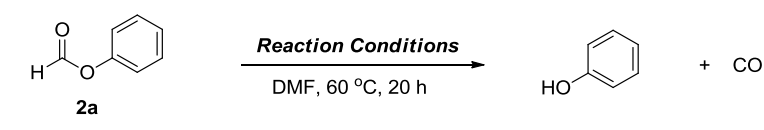

\begin{tabular}{|c|c|c|}
\hline Entry & Reaction conditions $^{a}$ & $\begin{array}{l}\text { Yield of } \\
\text { Phenol }(\%)^{b}\end{array}$ \\
\hline 1 & $\begin{array}{l}\mathrm{PdCl}_{2}(\mathrm{PhCN})_{2}(2.5 \mathrm{~mol} \%) \\
\text { xantphos }(2.5 \mathrm{~mol} \%), \mathrm{Et}_{3} \mathrm{~N} \text { (1.0 equiv) }\end{array}$ & 99 \\
\hline 2 & $\begin{array}{l}\mathrm{PdCl}_{2}(\mathrm{PhCN})_{2}(2.5 \mathrm{~mol} \%) \\
\text { xantphos }(2.5 \mathrm{~mol} \%)\end{array}$ & $<5$ \\
\hline 3 & $\mathrm{Et}_{3} \mathrm{~N}$ (1.0 equiv) & 99 \\
\hline 4 & $\mathrm{Et}_{3} \mathrm{~N}$ (1.0 equiv) at $40^{\circ} \mathrm{C}$ & 24 \\
\hline 5 & $\mathrm{Et}_{3} \mathrm{~N}(10 \mathrm{~mol} \%)$ & $<5$ \\
\hline
\end{tabular}

The conversion of $\mathbf{2 a}$ was monitored under various reaction conditions (Table 2). In the presence of a catalytic amount $(2.5$ mol\%) of $\mathrm{PdCl}_{2}(\mathrm{PhCN})_{2}$ and xantphos with 1.0 equiv of $\mathrm{Et}_{3} \mathrm{~N}$ (the same catalytic conditions as entry 9 in Table 1$),{ }^{8}$ phenol was 5 obtained quantitatively with evolution of carbon monoxide (entry 1). Removal of $\mathrm{Et}_{3} \mathrm{~N}$ from the entry 1 resulted in low conversion of $\mathbf{2 a}$ and phenol was obtained only in low yield (entry 2). However, with 1.0 equiv of $\mathrm{Et}_{3} \mathrm{~N}$ alone, 2a was fully converted and phenol was obtained in $99 \%$ yield (entry 3 ). Thus, $\mathrm{Et}_{3} \mathrm{~N}$ is 10 responsible for the conversion of $\mathbf{2 a}$. The reaction was slow at 40 ${ }^{\circ} \mathrm{C}$ (entry 4) and $\mathbf{2 a}$ was not almost converted in the presence of a catalytic amount of $\mathrm{Et}_{3} \mathrm{~N}$ (entry 5). Under the reaction conditions of entry 3, alkyl formates such as benzyl formate, hexyl formate, and 2-phenylethyl formate were not converted at all, which is 15 very reminiscent of the catalytic reaction (vide supra).

Various aryl bromides $(\mathbf{1 b}-\mathbf{n})$ reacted with $\mathbf{2 a}$ under the standard reaction conditions (Table 3). Aryl bromides bearing both electron-rich (entries 1 and 2) and electron-poor (entries 3-8) phenyl moieties gave the corresponding esters $(\mathbf{3 b}-\mathbf{j})$ in high 20 yields. Nitro (entry 7), formyl (entry 8) and cyano (entry 9) functionalities on the aryl ring tolerated under the reaction conditions. Gratifyingly, 11 bearing an ethynyl moiety afforded the corresponding ester (3l) without hydroesterification ${ }^{6}$ at the alkyne moiety (entry 11). Heterocycles such as pyridine and 25 thiophen were also adapted (entries 12 and 13). Besides 2a, the reaction of bromobenzene (1o) with aryl formates ( $\mathbf{2 b}-\mathbf{e})$ bearing electron-rich (entries 14 and 15) and electron-poor (entry 16) phenyl moieties gave the corresponding esters $(\mathbf{3 o}-\mathbf{q})$ in good to high yields. A sterically demanding aryl formate (2e) also 30 afforded $\mathbf{3 r}$ in high yield.

An alkenyl bromide (1p) reacted with $\mathbf{2 a}$ under the standard reaction conditions to give phenyl cinnamate (3s) in $66 \%$ yield (Scheme 2a). Iodobenzene (4) and phenyl triflate (5) also afforded phenyl benzoate $3 \mathrm{t}$ in $85 \%$ and $88 \%$ yields, respectively

35 (Scheme 2b). Although a chloro moiety on the aryl ring was intact under the standard reaction conditions (entry 3 in Table 3), an aryl chloride bearing an acetyl moiety (6) gave the corresponding ester $3 \mathbf{f}$ in $86 \%$ yield at the elevated temperature with $(i-\mathrm{Pr})_{2} \mathrm{EtN}$ as a base (Scheme 2c). In addition, benzyl
Table 3 Carbonylation of various substrates under the optimum reaction conditions. ${ }^{a}$

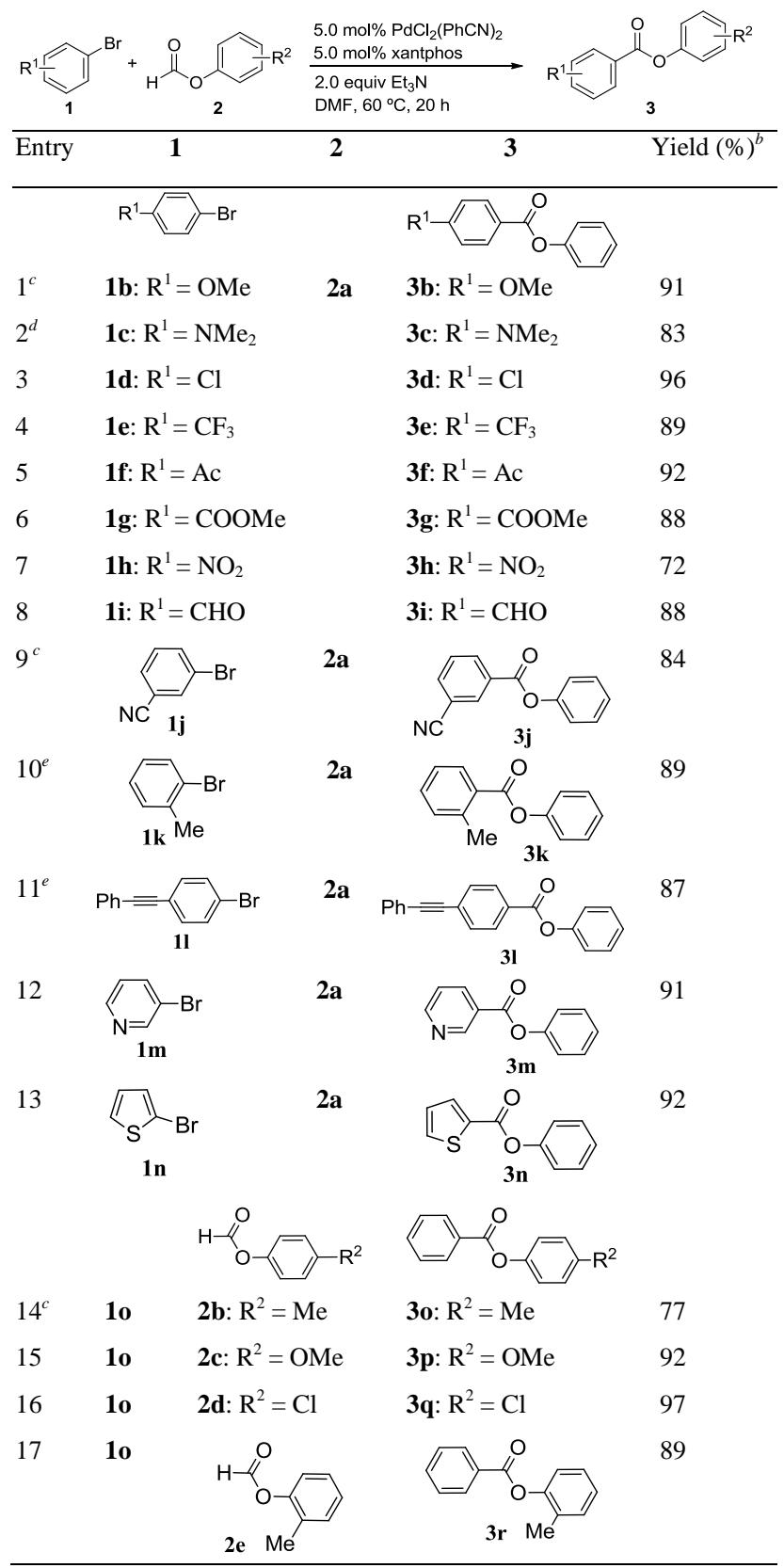

${ }^{a}$ Reaction conditions: aryl bromide $(\mathbf{1}, 0.50 \mathrm{mmol})$, aryl formate $(\mathbf{2}$, $0.75 \mathrm{mmol}), \mathrm{PdCl}_{2}(\mathrm{PhCN})_{2}(0.025 \mathrm{mmol}, 5.0 \mathrm{~mol} \%)$, xantphos $(0.025$ $\mathrm{mmol}, 5.0 \mathrm{~mol} \%), \mathrm{Et}_{3} \mathrm{~N}(1.0 \mathrm{mmol})$ in $\mathrm{DMF}(0.50 \mathrm{~mL})$ at $60{ }^{\circ} \mathrm{C}$ for 20 h. ${ }^{b}$ Isolated yields. ${ }^{c}$ At $70{ }^{\circ} \mathrm{C} .{ }^{d}$ At $80{ }^{\circ} \mathrm{C} .{ }^{e}$ At $90{ }^{\circ} \mathrm{C}$,

40 bromide (7) was smoothly converted to the corresponding phenyl ester $(3 \mathbf{u})$ by using $\mathrm{P}(\mathrm{OPh})_{3}$ as a ligand ${ }^{11}$ at $120{ }^{\circ} \mathrm{C}$ (Scheme $\left.2 \mathrm{~d}\right)$.

Noteworthy is that the present catalytic system realizes highly atom-efficient carbonylation. The reaction of $\mathbf{1 a}$ with 1 equiv of $\mathbf{2 a}$ in DMF $(0.1 \mathrm{~mL})$ smoothly proceeded and 3a was 45 obtained in $93 \%$ isolated yield (Scheme 3$).{ }^{8}$ The yield was almost comparable to that described in entry 9 in Table 1 . Other reactions employing $\mathbf{1 d}, \mathbf{1 e}$ and $\mathbf{1 f}$ with 1.0 equiv $\mathbf{2 a}$ afforded the corresponding products in high yield. The equimolar mixture of 10 and $2 \mathbf{c}$ in the presence of the Pd catalyst also gave $\mathbf{3 p}$ in high 50 yield. 
Scheme 2 Palladium-catalyzed carbonylation of various electrophiles with $\mathbf{2 a}$.

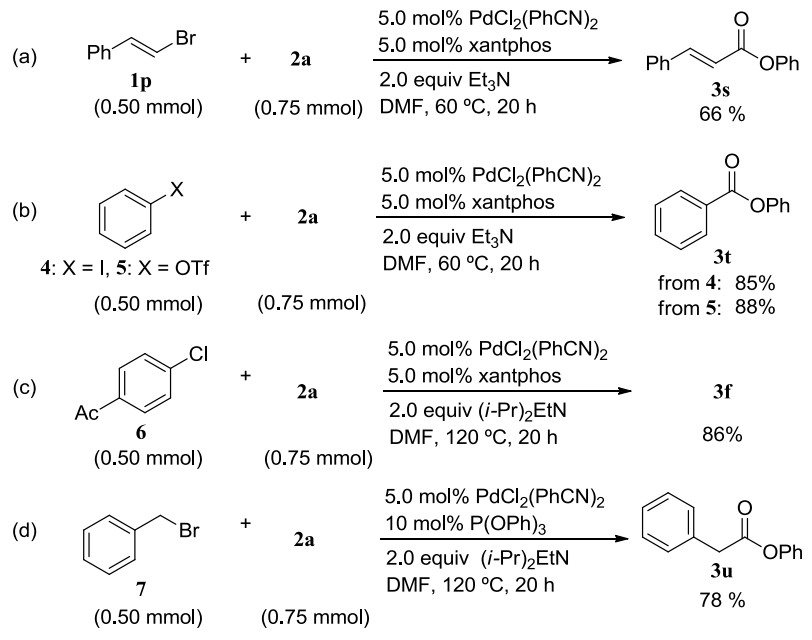

Scheme 3 Highly efficient esterification of $\mathbf{1}$ with $\mathbf{2}$ catalyzed by the palladium-xantphos system.

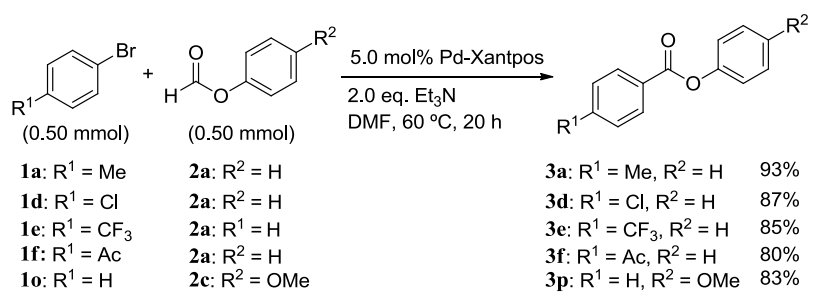

In conclusion, the carbonylation of aryl halides using aryl formates occurred at ambient pressure in the presence of Pdxantphos catalyst system to afford aryl esters in good to high yields. The reaction can be carried out without the use of external 5 carbon monoxide, and no directing group is required. During the reaction aryl formates were converted to carbon monoxide and the corresponding phenols by the aid of a base.

This work was supported by Grant-in-Aid for Scientific 10 Research on Innovative Areas ("Organic synthesis based on reaction integration" and "Molecular activation directed toward straightforward synthesis") from MEXT, Japan. T. F. is acknowledged to The Sumitomo Foundation for finantial support.

\section{Notes and references}

15 Department of Energy and Hydrocarbon Chemistry, Graduate School of Engineering, Kyoto University, Kyoto 615-8510, Japan.

E-mail: ytsuji@scl.kyoto-u.ac.jp; Fax: +81-75-383-2514;

Tel: $+81-75-383-2515$

$20 \dagger$ Electronic Supplementary Information (ESI) available: See DOI: $10.1039 / \mathrm{b} 000000 \mathrm{x} /$

1 For reviews, see; (a) A. Brennführer, H. Neumann and M. Beller, Angew. Chem., Int. Ed., 2009, 48, 4114-4133; (b) A. Bennführer, H.

25 Neumann and M. Beller, ChemCatChem, 2009, 1, 28-41; (c) C. Godard, B. K. Muñoz, A. Ruiz and C. Claver, Dalton Trans., 2008, 853-860; (d) G. Kiss, Chem. Rev., 2001, 101, 3435-3456; (e) B. E. Ali and H. Alper in Transition Metals for Organic Synthesis: Building Blocks and Fine Chemicals, eds. M. Beller and C. Bolm,
30

Wiley-VCH, Weinheim, 1998, pp. 49-67; (f) H. M. Colquhoun, D. J. Thompson and M. V. Twigg, Carbonylation. Direct Synthesis of Carbonyl Compounds, Plenum, New York, 1991, pp119-133, and references cited therein.

2 For carbonylation utilizing in situ generated carbon monoxide, see; $\mathrm{T}$.

35 Morimoto and K. Kakiuchi, Angew. Chem., Int. Ed., 2004, 43, 5580 5588 and references sitede therein.

3 (a) T. Schareina, A. Zapf, A. Cotte, M. Cotta and M. Beller, $A d v$. Synth. Catal., 2010, 352, 1205-1209; (b) S. Ko, C. Lee, M.-G. Choi, Y. Na and S. Chang, J. Org. Chem., 2003, 68, 1607-1610; (c) J.-F.

40 Carpentier, Y. Castanet, J. Brocard, A. Mortreux and F. Petit, Tetrahedron Lett., 1991, 32, 4705-4708; (d) J.-F. Carpentier, Y. Castanet, J. Brocard, A. Mortreux and F. Petit, Tetrahedron Lett., 1992, 33, 2001-2004; (e) J.-F. Carpentier, E. Finet, Y. Castanet, J. Brocard and A. Mortreux, Tetrahedron Lett., 1994, 35, 4995-4998;

45 (f) J.-F. Carpentier, Y. Castanet, A. Mortreux and F. Petit, $J$ Organomet. Chem., 1994, 482, 31-38.

4 Palladium-catalyzed esterification employing potassium oxalate monoesters was reported: R. Shang, Y. Fu, J. Li, S. Zhang, Q. Guo and L. Liu, J. Am. Chem. Soc., 2009, 131, 5738-5739.

505 (a) S. D. Friis, R. H. Taaning, A. T. Lindhardt and T. Skrydstrup, J. Am. Chem. Soc., 2011, 133, 18114-18117; (b) P. Hermange, A. T. Lindhardt, R. H. Taaning, K. Bjerglund, D. Lupp and T. Skrydstrup, J. Am. Chem. Soc., 2011, 133, 6061-6071; (c) P. Hermange, T. M. Gøgsig, A. T. Lindhardt, R. H. Taaning and T. Skrydstrup, Org. Lett., 2011, 13, 2444-2447.

6 Y. Katafuchi, T. Fujihara, T. Iwai, J. Terao and Y. Tsuji, Adv. Synth. Catal., 2011, 353, 475-482.

7 (a) Very recently, Manabe et al. reported the Pd-catalyzed carbonylation with phenyl formate. ${ }^{7 b}$ This publication prompted us to 60 report our independent study ${ }^{7 \mathrm{c}, \mathrm{d}}$ featuring atom-efficient carbonylation with only 1 equiv of phenyl formate. (b) T. Ueda, H. Konishi and K. Manabe, Org. Lett., 2012, 14, 3100-3103; (c) T. Hosoki, Y. Katafuchi, T. Iwai, T. Fujihara, J. Terao and Y. Tsuji, 58th Symposium on Organometallic Chemistry, Japan, 2011, P3B-12, presented on September 9, Nagoya, Japan; (d) T. Hosoki, Y. Katafuchi, T. Iwai, T. Fujihara, J. Terao and Y. Tsuji, International Symposium on Catalysis and Fine Chemicals 2011 (C\&FC2011), 2011, P1-35, presented on December 5, Nara, Japan.

8 See ESI for detail†.

709 Abbreviation: $o$-tol $=2$-methylphenyl, $\mathrm{Cy}=$ cyclohexyl, dppe $=1,2-$ bis(diphenylphosphino)ethane, $\quad \mathrm{dppp}=1,2$ bis(diphenylphosphino)propane, $\quad \mathrm{dppf}=1,2$-bis(diphenylphosphino)ferrocene, $\quad r a c$-binap $=$ bis(diphenylphosphino) $-1,1^{\prime}$ binaphthyl, $\quad$ xantphos: 4,5-bis(diphenylphosphino)-9,9dimethylxanthene.

10 J. R. Martinelli, D. A. Watson, D. M. M. Freckmann, T. E. Barder and S. L. Buchwald, J. Org. Chem., 2008, 73, 7102-7107.

11 A. M. Trzeciak, H. Bartosz-Bechowski, Z. Ciunik, K. Niesyty and J. J. Ziólkowski, Can. J. Chem., 2001, 79, 752-759. 